\title{
Changes in the Racial Composition of Phytophthora sojae in Australia Between 1979 and 1996
}

M. J. Ryley and N. R. Obst, Queensland Department of Primary Industries, P.O. Box 102, Toowoomba, Queensland 4350, Australia, and Cooperative Research Centre for Tropical Plant Pathology, University of Queensland, St. Lucia, Queensland 4072, Australia; and J. A. G. Irwin and A. Drenth, Cooperative Research Centre for Tropical Plant Pathology, University of Queensland, St. Lucia, Queensland 4072, Australia

\section{ABSTRACT}

Ryley, M. J., Obst, N. R., Irwin, J. A. G., and Drenth, A. 1998. Changes in the racial composition of Phytophthora sojae in Australia between 1979 and 1996. Plant Dis. 82:1048-1054.

Surveys of commercial soybean fields, disease nurseries, and trial plots of soybean were conducted throughout eastern Australia between 1979 and 1996, and 694 isolates of Phytophthora sojae were collected and classified into races. Fourteen races, 1, 2, 4, 10, 15, and 25, and eight new races, 46 to 53 , were identified, but only races $1,4,15,25,46$, and 53 were found in commercial fields. Races 1 and 15 were the only races found in commercial fields in the soybeangrowing areas of Australia up until 1989, with race 1 being the dominant race. Race 4 was found in central New South Wales in 1989 on cultivars with the Rps1a gene, and it is now the dominant race in central and southern New South Wales. Races 46 and 53 have only been found once, in southern New South Wales, and race 25 was identified in the same region in 1994 on a cultivar with the Rps $1 \mathrm{k}$ gene. Only races 1 and 15 have been found in the northern soybeangrowing regions, with the latter dominating, which coincides with the widespread use of cultivars with the Rps 2 gene. Changes in the race structure of the P. sojae population from commercial fields in Australia follow the deployment of specific resistance genes.

Soybean (Glycine max (L.) Merr.) has been grown commercially in Australia for over 30 years, but until the early 1970s, the annual production was less than 1,000 tonnes (19). The release of the high-yielding cultivars Bragg, Davis, Hill, and Lee resulted in a dramatic increase in the area under production, particularly in southern Queensland (19). At present, soybeans are grown commercially in discrete areas from approximately $15^{\circ} 40^{\prime} \mathrm{S}$ to $36^{\circ} 30^{\prime} \mathrm{S}$ (Fig. 1), with the maturity group ranging from IX in the north to II in the south. The major production areas are in southern Queensland (irrigated and raingrown), north coastal New South Wales (raingrown), central and southern New South Wales, and northern Victoria (mostly irrigated).

Soilborne diseases were generally considered to have little effect on soybean yields in the early years of production in Australia. However, this situation changed in 1979 when Phytophthora root and stem rot, caused by Phytophthora sojae Kauf. \& Gerd. (syn. P. megasperma Drechs. f. sp. glycinea Kuan \& Erwin), was recorded for the first time in Australia on the Darling Downs in southern Queensland (16). In

Corresponding author: M. J. Ryley

E-mail address: ryleym@ dpi.qld.gov.au

Accepted for publication 9 June 1998.

Publication no. D-1998-0724-01R

(C) 1998 The American Phytopathological Society
1979-80 and 1980-81, the disease was recorded in other areas in southern Queensland (Queensland Department of Primary Industries, unpublished records) and central New South Wales (NSW Agriculture, unpublished records). Initially, losses in the first few seasons in southern Queensland were severe, with up to $90 \%$ plant loss for the widely grown susceptible cultivars such as Semstar, P24, Fitzroy, and Bragg (18). Assessments of the resistance of commercial cultivars to $P$. sojae revealed that most were susceptible, with only the cultivars Davis and Hill having acceptable levels of field resistance. The high levels of field resistance of these two cultivars to race 1 were confirmed in laboratory root inoculation experiments (12) and in yield loss trials (20). Fortunately, Davis was a cultivar that was well adapted to southern Queensland, and crosses with cv. Bragg (to minimize the shattering in Davis) were in an advanced stage when Phytophthora root rot appeared. Adoption of Davis, and later cultivars with a Davis background, was largely responsible for a decrease in the damage from $P$. sojae in southern Queensland.

Although the disease had been recorded in New South Wales in 1980 (NSW Agriculture, unpublished records), extensive disease surveys were not conducted until 1985 (10). Isolates of $P$. sojae were collected from some cultivars, such as Chaffey, Farrer, Lawry, and Southee, but not from others such as Bowyer and Ridley. In recent years, losses from Phytophthora root and stem rot have been so severe in the upper Lachlan Valley of southern New South Wales that growers are now reluctant to plant soybeans. Breeding for resistance to $P$. sojae has become an important component of the major soybean breeding programs in Australia.

Thirteen resistance genes (Rps), at seven loci, that confer immunity or partial resistance to one or more races of $P$. sojae have been characterized $(3,25)$, and three more have been identified but not numbered (17). Two types of resistance to $P$. sojae have been characterized, immunity or racespecific resistance conferred by 12 of the described genes, and field resistance (syn. partial resistance, tolerance, rate-reducing resistance, root resistance) conferred by the Rps 2 gene. At one time, this latter type of resistance was believed to be race nonspecific, but recently it has been shown to be race specific $(21,27,28)$.

Since $P$. sojae was recorded in the United States in 1955 (26), 45 races have been classified on differential soybean genotypes (1), and many more isolates with unique virulence patterns have been identified but not given a race number $(25,29,31)$. Temporal changes in the racial composition of $P$. sojae in North America have been described by many workers $(2,14,25,31)$ and are markedly influenced by the resistance genes that have been used in commercial cultivars. Restriction fragment length polymorphism (RFLP) analysis revealed an extremely low level of genotypic diversity in an Australian $P$. sojae population of 84 isolates. The low levels of diversity observed (one multilocus RFLP genotype occurred in over 95\% of all isolates) compared with the high level of diversity observed in U.S. populations indicates that the Australian population was most likely established by a single introduction of the pathogen (7).

The current investigation summarizes all virulence data from the first occurrence of P. sojae in Australia in 1979 to 1996 . The aims of this long-term study were to provide an insight into (i) the long-term stability of the $P$. sojae population, (ii) the origin, dynamics, and epidemiology of the $P$. sojae population, (iii) the long-term effectiveness of current resistant sources, (iv) comparisons in the racial dynamics between trial sites and disease nurseries, and commercially grown soybean crops, 
(v) differences in the racial dynamics between Australia and other countries where Phytophthora root rot occurs, and (vi) the influence of host gene deployment on the evolution of $P$. sojae in Australia from a simple genetic base. Such information is vital to improve present and future strategies for resistance breeding in soybean against $P$. sojae.

\section{MATERIALS AND METHODS}

Regions surveyed. Soybean production areas were grouped into two broad geographic regions for sampling commercial crops and trial sites (Fig. 1). Within the Queensland and northern New South Wales region, the following soybean growing areas can be identified: the Burdekin River irrigation area of northern Queensland (not shown in Fig. 1), Central Highlands, Darling Downs, St. George Irrigation Area, Moreton and Burnett districts of southern Queensland, and the inland and coastal districts of northern New South Wales. The central and southern New South Wales and northern Victoria region comprises the Macquarie and Lachlan river valleys of central New South Wales and the Murrumbidgee and Murray river valleys (including associated irrigation areas) of southern New South Wales and northern Victoria (Fig. 1).

Collection of isolates: Commercial crops. Between 1979 and 1996, commercial soybean crops in soybean-growing areas were surveyed annually for Phytophthora root and stem rot. The frequency of visits in each area depended on the intensity of soybean cultivation, reports of disease problems, and previous recordings of the pathogen in the area. When the disease was found in a crop, data on the cultivar, disease incidence, and field history were collected. Up to five plants displaying disease symptoms of wilting and a sunken dark stem lesion were removed, and either whole plants or 20-cm-long sections of stems with the advancing upper margin of the lesion were stored in moist plastic bags under refrigeration until processed (within $24 \mathrm{~h}$ ). Surveys of soybean crops for Phytophthora root rot were conducted in southern New South Wales and northern Victoria between 1985 and 1988 by Heritage et. al. (10).

Collection of isolates: Trial sites. Diseased plants were also collected from trial sites and disease nurseries at several localities in eastern Australia, most notably Hermitage Research Station and the LIRAC (Lachlan Irrigation Research Advisory Council) field site at Condobolin, New South Wales (Fig. 1), a testing site for breeding lines from the New South Wales Agriculture soybean breeding program. In the 1993-94 and 1995-96 seasons, areas at the LIRAC field site and at Hermitage Research Station, which had been used as disease nurseries for several years, were planted with the cultivars Ruse or Ross (both believed not to possess Rps genes) to gain an insight into the racial diversity of the $P$. sojae populations that had been exposed to a variety of different Rps genes in breeding material. Between the R1 and R3 growth stages, approximately 120 plants with stem lesions typical of $P$. sojae were collected at random from each of the trial sites.

Isolation and storage. $P$. sojae isolates were obtained by surface sterilizing a 20 $\mathrm{mm}$ section of stem at the advancing margin of a lesion with sodium hypochlorite ( $1 \%$ available chlorine) for $3 \mathrm{~min}$ or by igniting a stem piece previously dipped in $70 \%$ ethanol for $10 \mathrm{~s}$. After surface sterilization, small parts of these stem pieces were submerged in freshly poured corn meal agar (CMA)-3P medium (8) or CMAPVP (50 ppm penicillin, 200 ppm vancomycin, $50 \mathrm{ppm}$ pimaricin) medium. Two single hyphal tip cultures from each mass isolate were stored on agar disks in sterile distilled water, or on CMA slopes under paraffin oil, in 25-ml MacCartney bottles. From 1993 onwards, hyphal tip isolates were stored on CMA agar disks under 5\% dimethyl sulfoxide (DMSO) in 1-ml vials immersed in liquid nitrogen. More than $95 \%$ of isolates were classified into races within 4 weeks of collection, with the remainder being stored for up to 4 months under liquid nitrogen before being classified.

Inoculum preparation. Inoculum for race classifications was produced by transferring five or six 5-mm-diameter plugs from the margin of a 4-day-old colony to $100 \mathrm{ml}$ of $\mathrm{V} 8$ juice broth (5) in 250-ml Erlenmeyer flasks. The flasks were incubated on a laboratory bench at $24^{\circ} \mathrm{C} \pm 4^{\circ} \mathrm{C}$ under natural diffuse light. After 7 days, the mycelium was harvested, washed in distilled water, squeezed between absorbent paper towels, and transferred to sterile 80-mm-diameter petri dishes.

Race classification. The soybean genotypes used in the differential set to classify the isolates of $P$. sojae changed during the course of the study as a result of more resistance genes being identified, and isolines becoming available in Australia

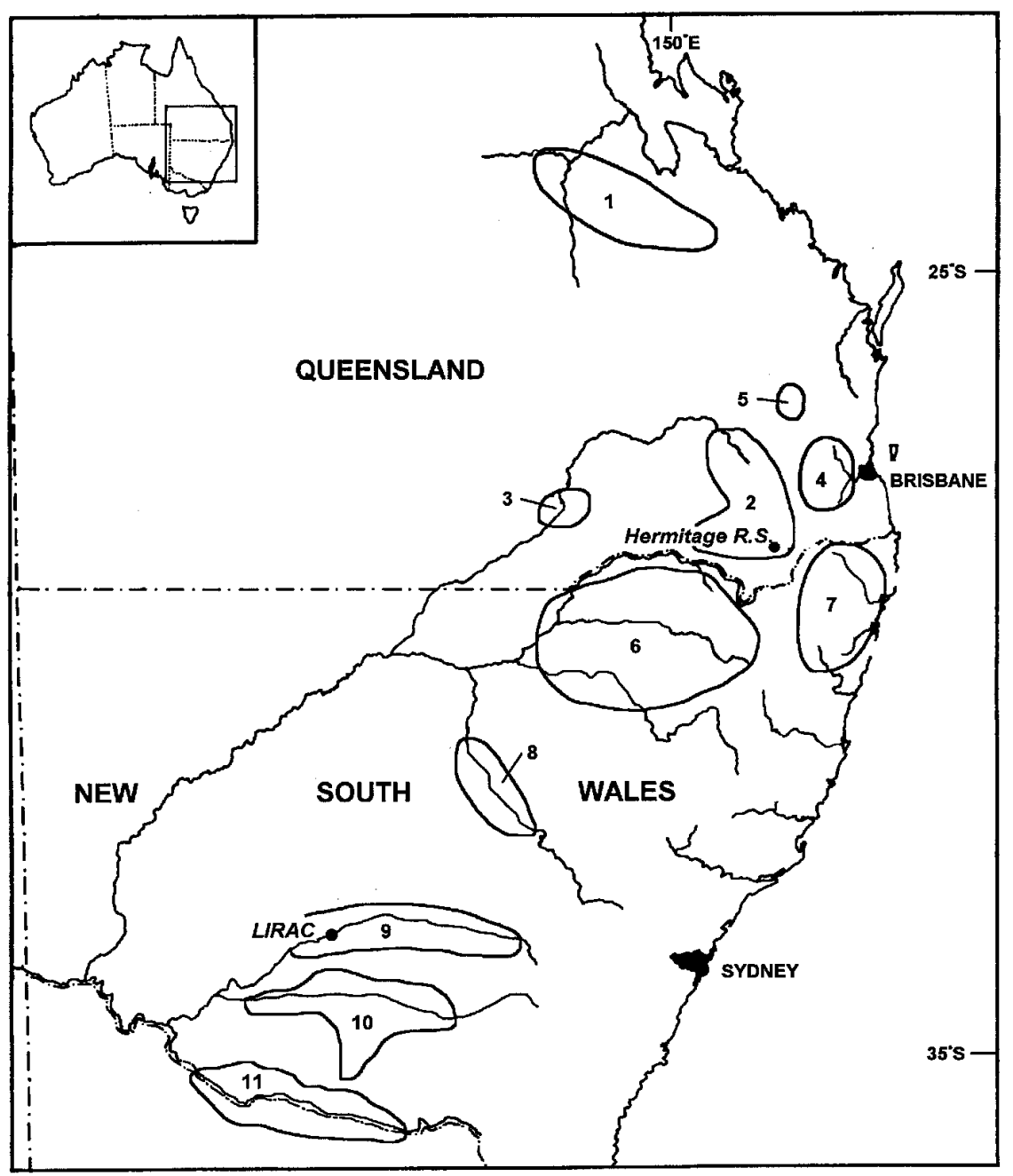

Fig. 1. Major soybean production areas in Australia. 1. Central Highlands. 2. Darling Downs. 3. St. George Irrigation Area. 4. Moreton District. 5. Burnett District. 6. Inland northern New South Wales. 7. Coastal northern New South Wales. 8. Macquarie Valley. 9. Lachlan Valley. 10. Murrumbidgee Valley. 11. Murray Valley. 
(Table 1). Fifteen seeds of each differential soybean line were planted in sterile sandpeat $(1: 10)$ potting mix in 8 -cm pots that were kept at $26^{\circ} \mathrm{C} \pm 1{ }^{\circ} \mathrm{C}$ under a 14-h light (380 to $400 \mu \mathrm{E} \cdot \mathrm{m}^{-2} \cdot \mathrm{s}^{-1}$ ), 10 -h dark regime. After 5 days, the seedlings were thinned to 10 uniform seedlings per pot. Seedlings were inoculated by placing a weft of mycelium in a short slit made in the hypocotyl approximately $10 \mathrm{~mm}$ below the cotyledon. Each pot was covered with a moistened plastic bag and incubated under the conditions described above. The bags were removed after 1 day, and the seedlings were rated as susceptible (hypocotyl collapsed) or resistant (no lesion or restricted nonkilling lesion) 5 days later. Approxi- mately $90 \%$ of the isolates gave a clear-cut reaction on the differential set, killing $100 \%$ of susceptible genotypes or none of the resistant genotypes, but the remaining isolates killed varying proportions of one or more of the differentials. These isolates were retested to confirm their atypical reactions. Isolates that killed $>70 \%$ of seedlings of a particular differential after the second test were considered virulent on that differential (typical reaction), and isolates that killed $<70 \%$ but $>30 \%$ of a differential were termed atypical. Atypical isolates have been previously reported in Australia (10,18). Inoculated seedlings with nonkilling lesions after 5 days of incubation were treated as resistant.

Table 1. Soybean genotypes used to classify Australian isolates of Phytophthora sojae between 1979 and $1996^{\mathrm{y}}$

\begin{tabular}{|c|c|c|c|c|c|}
\hline Rps gene & $\begin{array}{l}\text { 1979-80, } \\
1989-90\end{array}$ & $\begin{array}{c}\text { 1990-91, } \\
1993-94\end{array}$ & $1994-95$ & $1995-96$ & May 1996 \\
\hline$r p s$ & & & & HARO(1-7)1 & HARO(1-7)1 \\
\hline 1a & Harosoy $63 * z$ & Harosoy $63 *$ & HARO1272 * & HARO1272 * & HARO $1272 *$ \\
\hline $1 b$ & Sanga & Sanga & HARO1372 * & HARO13 & HARO13 \\
\hline $1 \mathrm{c}$ & WellsII & WellsII & OX682 & OX682 & OX682 \\
\hline $1 d$ & PI103091 & PI103091 & PI103091 & HARO16 & HARO16 \\
\hline $1 \mathrm{k}$ & & Kingwa & HARO1572 * & Kingwa & Kingwa \\
\hline $3 a$ & PI86972-1 & PI86972-1 & HARO3272 * & L83-570 & L83-570 \\
\hline $3 b$ & $\ldots$ & $\ldots$ & $\ldots$ & L88-1479 & L88-1479 \\
\hline $3 c$ & $\ldots$ & $\ldots$ & $\ldots$ & $\ldots$ & X572-373 \\
\hline 4 & $\ldots$ & $\ldots$ & $\ldots$ & L85-2352 & L85-2352 \\
\hline 5 & $\ldots$ & $\ldots$ & HARO5272 * & L85-3059 & L85-3059 \\
\hline 6 & Altona & Altona & Altona & L89-1581 & L89-1581 \\
\hline 7 & Harosoy & Harosoy & Harosoy & Harosoy & Harosoy \\
\hline
\end{tabular}

y Seed of Harosoy63, Sanga, WellsII, PI103091, PI86972-1, Altona, and Harosoy were obtained from K. L. Athow, Purdue University, West Lafayette, Indiana, and the remainder were from R. I. Buzzell, Agriculture and Agri-food Canada, Ontario, Canada. The lines with the L prefix originated from R. L. Bernard, University of Illinois, Urbana.

$\mathrm{z} *$ Genotypes also contain the Rps7 gene according to Anderson and Buzzell (3).

Table 2. Races of Phytophthora sojae recorded in Australia between 1979 and 1996

\begin{tabular}{|c|c|c|c|}
\hline Race & Formula $(R p s)$ & First record & Present distribution \\
\hline 1 & 7 & $1979-80$ & So. Qld.; no., cent., so. NSW \\
\hline $1 \mathrm{at}^{\mathrm{x}}$ & $7 \pm 1 b, 1 c, 5^{* y}, 6$ & $1979-80$ & So. Qld.; cent., so. NSW \\
\hline 15 & $3 a, 5^{*}, 7$ & $1980-81$ & So., no. Qld.; no., cent., so. NSW \\
\hline 15at & $3 \mathrm{a}, 5^{*}, 7 \pm 1 \mathrm{a}, 1 \mathrm{~b}, 1 \mathrm{~d}, 4^{*}, 6$ & $1980-81$ & So. Qld. \\
\hline 4 & $1 \mathrm{a}, 1 \mathrm{c}, 7$ & $1989-90$ & $\begin{array}{l}\text { So. NSW; so. Qld. (Hermitage RS } \\
\text { only) }\end{array}$ \\
\hline 46 & $1 \mathrm{a}, 1 \mathrm{c}, 3 \mathrm{a}, 5^{*}, 7$ & $1990-91$ & So. NSW ( 1 isolate) \\
\hline 4at & $1 \mathrm{a}, 1 \mathrm{c}, 7 \pm 1 \mathrm{~b}, 1 \mathrm{~d}, 1 \mathrm{k}, 5^{*}$ & $1991-92$ & $\begin{array}{l}\text { So. NSW; so. Qld. (Hermitage RS } \\
\text { only) }\end{array}$ \\
\hline $50^{\mathrm{z}}$ & $4 *, 6,7$ & $1992-93$ & So. Qld. (Hermitage RS only) \\
\hline 2 & $1 b, 7$ & 1993-94 & So. Qld. (Hermitage RS only) \\
\hline 10 & $1 \mathrm{~b}, 3 \mathrm{a}, 5^{*}, 7$ & 1993-94 & So. Qld. (Hermitage RS only) \\
\hline 25 & $1 \mathrm{a}, 1 \mathrm{~b}, 1 \mathrm{c}, 1 \mathrm{k}, 7$ & 1993-94 & So. NSW \\
\hline 47 & $1 \mathrm{a}, 1 \mathrm{~b}, 1 \mathrm{c}, 7$ & 1993-94 & So. NSW (LIRAC only) \\
\hline 48 & $5^{*}, 7$ & 1993-94 & So. Qld. (Hermitage RS only) \\
\hline 25at & $1 \mathrm{a}, 1 \mathrm{~b}, 1 \mathrm{c}, 1 \mathrm{k}, 7 \pm 1 \mathrm{~d}, 5,6$ & $1994-95$ & So. NSW \\
\hline 49 & 1a, $1 \mathrm{c}, 4,6,7$ & 1994-95 & So. NSW (LIRAC only) \\
\hline 48at & $5,7 \pm 1 b, 1 c, 6$ & $1995-96$ & So. Qld. (Hermitage RS only) \\
\hline 51 & $1 c, 5,6,7$ & $1995-96$ & So. Qld. (Hermitage RS only) \\
\hline 52 & $3 b, 5,7$ & $1995-96$ & So. Qld. (Hermitage RS only) \\
\hline 2at & $1 \mathrm{~b}, 7 \pm 1 \mathrm{c}, 5,6$ & $1995-96$ & So. Qld. (Hermitage RS only) \\
\hline 53 & $1 \mathrm{a}, 1 \mathrm{~b}, 1 \mathrm{c}, 3 \mathrm{a}, 5,7$ & $1995-96$ & So. NSW \\
\hline
\end{tabular}

$\mathrm{x}$ at $=$ atypical isolates. Such isolates of races $1,4,15,25$, and 48 killed $>30 \%$ but $<70 \%$ of the seedlings of the differentials containing the genes listed after the \pm sign.

y $*$ The differential lines containing the genes Rps 4 and Rps 5 were not included in the differential set prior to 1994.

${ }^{\mathrm{z}}$ Isolates were virulent on the genes Rps6 and Rps7 and were designated as race 13. Subsequent retesting in 1995-96 revealed that they were also virulent on the Rps 4 gene.

\section{RESULTS}

A total of 694 isolates were collected during the survey period, $36 \%$ of isolates from commercial crops and the remainder from trial sites. Fewer isolates were collected in commercial crops in each area between 1988-89 and 1995-96 because the areas sown to soybean decreased, primarily due to competition from crops with higher returns, and drought. Crops planted in these years were usually in fields with a short history of soybean production. Fourteen races of $P$. sojae were identified in Australia (Table 2), with eight of these, races $2,10,47,48,49,50,51$, and 52, found only at two trial sites (Hermitage Research Station or the LIRAC trial). The new races, 46 to 53 , have virulence patterns that have not previously been described (Table 2).

Commercial crops: Queensland and northern New South Wales. Between 1979-80 and 1987-88 in Queensland and northern New South Wales, race 1 and atypical race 1 isolates were found in all production areas where Phytophthora root and stem rot had been recorded, and together they comprised approximately 93\% of all isolates collected (Tables 3 and 4). The remaining isolates were characterized as race 15 or as atypical race 15 and were found only in the Moreton district and on the Darling Downs. Although race 15 had been first recorded in the Moreton district in 1980-81, it was not found on the Darling Downs until 1984-85, and then only two isolates were found up until 1987-88. Isolates of race 1 and race 15 (typical and atypical) were collected from many cultivars, including Semstar, P24, Fitzroy, Bragg, Flegler, and Wills, in all districts. Although race 1 was also recorded on these cultivars on the Darling Downs, the two race 15 isolates from this region were found only on cv. Davis, which has the resistance gene Rps2 (Table 3). Losses recorded between 1979-80 and 1982-83 ranged from a trace level to $90 \%$ plant loss in individual fields, but after that period, losses were rarely greater than $10 \%$ (data not shown).

During the growing seasons between 1988-89 and 1995-96, 21 isolates were collected from commercial fields in the region, comprising seven race 1 isolates and fourteen race 15 isolates. Race 15 was recorded on the north coast of New South Wales for the first time in 1993-94. Race 15 isolates were obtained only from the cultivars Manark (Davis $\times$ Bragg) and Davis, both of which possess the Rps 2 gene, and losses were mostly less than $5 \%$. In all cases, plants infected with race 15 had an extensive root rot and a short stem lesion restricted to just above $(5 \mathrm{~cm})$ the soil line.

P. sojae has not been isolated from soybeans in central Queensland (Biloela and Emerald irrigation area), near Grafton on the north coast of New South Wales, or in coastal areas of southern Queensland. 
Commercial crops: Central and southern New South Wales and northern Victoria. Race 4 was the dominant race found in commercial fields of soybean in the Lachlan, Murrumbidgee, and Murray valleys between 1988-89 and 1995-96 (Tables 3 and 4). Phytophthora root and stem rot was not found in northern Victoria. Isolates of this race were obtained from Bowyer, Lachlan, Lorna, Ridley, and Wallis, with plant losses ranging up to $20 \%$ in commercial situations. Lachlan, Ridley, and Lorna are believed to possess the Rps 1a gene, which was derived from one of their parents, Calland (39). Race 1 and atypical race 1 were found in all four areas in central and southern New South Wales on all cultivars (Table 4 ). Race 15 , found only in the Murrumbidgee and Murray valleys, was isolated predominantly from the cultivar Stephens, which was released for commercial use in 1987. Plant losses in affected crops of Stephens were low $(<10 \%)$. One isolate each of the previously undescribed races 46 and 53 was found on cultivar Bowyer in the Murray and Murrumbidgee valleys, respectively (Table 4). In 1994-95, and again in 1996, race 25 isolates and atypical race 25 isolates were obtained from seed increase blocks of the recently released cultivar Banjalong near
Wirrinya, in the Upper Lachlan Valley. Race 25 had been found the previous season on that cultivar and from a bulk planting of the cultivar Ruse at the LIRAC trial site. Banjalong, a cross between a narrowleafed selection of Calland and Williams 82 , is believed to possess the Rps 1k gene, derived from Williams 82 . It had been selected for release in the Upper Lachlan Valley because of its immunity to races 1 , 4 , and 15 .

Trial sites: Queensland and northern New South Wales. Most of the isolates of $P$. sojae collected at trial sites in this region were from the Hermitage Research Station in southern Queensland. All the isolates

Table 4. Occurrence of races of Phytophthora sojae in commercial soybean crops in Australia, 1979 to 1996

\begin{tabular}{|c|c|c|}
\hline Region and area & Races & Virulence genes \\
\hline \multicolumn{3}{|l|}{ Queensland and northern NSW } \\
\hline Central Highlands & . & $\ldots$ \\
\hline Darling Downs & $1,15,15 \mathrm{at}^{\mathrm{z}}$ & $7 ; 3 a, 5,7 ; 3 a, 5,7 \pm 1 b$ \\
\hline St. George Irrigation Area & 1,1 at & $7 ; 7 \pm 1 b, 6$ \\
\hline Moreton & 1,1 at, 15,15 at & $7 ; 7 \pm 1 b, 1 d, 6 ; 3 a, 5,7 ; 3 a, 5,7 \pm 1 b, 6$ \\
\hline Burnett & 1,1 at & $7 ; 7 \pm 1 b, 1 c$ \\
\hline Inland northern NSW & 1 & 7 \\
\hline Coastal northern NSW & 1,1 at, 15 & $7 ; 7 \pm 1 b, 6 ; 3 a, 5,7$ \\
\hline \multicolumn{3}{|c|}{ Central and southern NSW and northern Victoria } \\
\hline Macquarie River Valley & 1,1 at & $7 ; 7 \pm 6$ \\
\hline Lachlan River Valley & 1at, 4, 4at, 25, 25at & $\begin{array}{l}7 \pm 1 \mathrm{~d} ; 1 \mathrm{a}, 1 \mathrm{c}, 7 ; 1 \mathrm{a}, 1 \mathrm{c}, 7 \pm 1 \mathrm{~d} ; 1 \mathrm{a}, 1 \mathrm{~b} \\
1 \mathrm{c}, 1 \mathrm{k}, 7 ; 1 \mathrm{a}, 1 \mathrm{~b}, 1 \mathrm{c}, 1 \mathrm{k}, 7 \pm 1 \mathrm{~d}, 5,6\end{array}$ \\
\hline Murrumbidgee River Valley & 1, 1at, 4, 4at, 15, 53 & $\begin{array}{l}7 ; 7 \pm 1 d ; 1 a, 1 c, 7 ; 1 a, 1 c, 7 \pm 1 d, 5,6 \\
3 \mathrm{a}, 5,7 ; 1 \mathrm{a}, 1 \mathrm{~b}, 1 \mathrm{c}, 3 \mathrm{a}, 5,7\end{array}$ \\
\hline $\begin{array}{l}\text { Murray River Valley } \\
\text { (Finley, Jerilderie, Berrigan) }\end{array}$ & $1,4,15,46$ & $7 ; 1 \mathrm{a}, 1 \mathrm{c}, 7 ; 3 \mathrm{a}, 5,7 ; 1 \mathrm{a}, 1 \mathrm{c}, 3 \mathrm{a}, 5,7$ \\
\hline Northern Victoria & $\ldots$ & $\ldots$ \\
\hline
\end{tabular}

Table 3. Numbers of isolates and races of Phytophthora sojae in commercial crops and at trial sites, virulence genes identified, and resistance genes (Rps) deployed in commercial crops in southern Queensland and northern New South Wales, and in central and southern New South Wales and northern Victoria, 1979-96

\begin{tabular}{|c|c|c|c|c|c|c|c|}
\hline \multirow[b]{2}{*}{ Year } & \multicolumn{4}{|c|}{ Commercial crops } & \multicolumn{3}{|c|}{ Trial sites } \\
\hline & No. isolates & Races $^{\mathbf{v}}$ & Vir. genesw & Rps genes $^{\mathrm{x}}$ & No. isolates & Races $^{\mathbf{v}}$ & Vir. genes $^{w}$ \\
\hline \multicolumn{8}{|c|}{ Qld. and no. NSW } \\
\hline $1979-80$ & 9 & 1,1 at $^{\mathrm{y}}$ & 7 & & 9 & 1,1 at & 7 \\
\hline $1980-81$ & 38 & 1, 1at, 15at & $3 a, 5 * z$ & 2 & 2 & 1 & \\
\hline $1981-82$ & 20 & 1,1 at, 15 & & 2 & 7 & 1 & \\
\hline $1982-83$ & 21 & 1,1 at, 15 & & 2 & 9 & 1,1 at & \\
\hline $1983-84$ & 15 & 1,1 at, 15 & & 2 & 9 & 1,1 at & \\
\hline $1984-85$ & 6 & 1,1 at, 15 & & 2 & 6 & 1,1 at & \\
\hline $1985-86$ & 0 & & & & 2 & 1,1 at & \\
\hline $1986-87$ & 1 & 15 & & 2 & 7 & 1,1 at & \\
\hline $1987-88$ & 5 & 15,1 & & 2 & 7 & 1,1 at & \\
\hline $1988-89$ & 0 & & & & 1 & 15 & $3 a, 5^{*}$ \\
\hline $1989-90$ & 1 & 15 & & 2 & 14 & 15,15 at, 1at, 1 & \\
\hline $1990-91$ & 9 & 15,1 & & 2 & 10 & $15,1,15$ at & \\
\hline 1991-92 & 0 & & & & 1 & 1 & \\
\hline $1992-93$ & 0 & & & & 12 & 1,1 at, 50,15 & $4^{*}, 6$ \\
\hline 1993-94 & 8 & 15,1 & & 2 & 119 & $\begin{array}{l}15,1,48,50,1 \text { at, } 15 \mathrm{at}, \\
4,2,10\end{array}$ & $1 \mathrm{a}, 1 \mathrm{~b}, 1 \mathrm{c}$ \\
\hline 1994-95 & 1 & 15 & & 2 & 11 & 15,15 at, $1,2,4,50$ & \\
\hline $1995-96$ & 2 & 1,15 & & 2 & 67 & $\begin{array}{l}15,15 \text { at, } 1,1 \text { at, } 50,2, \\
\text { 2at, 48at, 51, } 52\end{array}$ & $3 b$ \\
\hline \multicolumn{8}{|c|}{ Cent. and so. NSW } \\
\hline 1989-90 & 2 & 4 & $1 \mathrm{a}, 1 \mathrm{c}$ & $1 \mathrm{a}$ & 0 & & \\
\hline $1990-91$ & 29 & $4,1,1$ at, 15,46 & $3 a, 5^{*}, 7$ & $1 \mathrm{a}$ & 13 & 4,1 & $1 \mathrm{a}, 1 \mathrm{c}$ \\
\hline $1991-92$ & 11 & $4,1,4$ at, 15 & & $1 \mathrm{a}$ & 13 & 4 & \\
\hline $1992-93$ & 4 & 4, 1 at, 15 & & $1 \mathrm{a}$ & 9 & 4at, 4, 1at & \\
\hline 1993-94 & 20 & $4,15,4$ at & & $1 \mathrm{a}$ & 91 & 4, 4at, 25, 1at, 25at, 47 & $1 \mathrm{~b}, 1 \mathrm{k}$ \\
\hline 1994-95 & 35 & $4,4 \mathrm{at}, 15,25,25 \mathrm{at}$ & $1 \mathrm{~b}, 1 \mathrm{k}$ & $1 \mathrm{a}, 1 \mathrm{k}$ & 23 & $4,4 \mathrm{at}, 49$ & $4^{*}, 6$ \\
\hline $1995-96$ & 15 & 1, 4, 4at, 15, 25, 53 & & $1 \mathrm{a}, 1 \mathrm{k}$ & 0 & & \\
\hline
\end{tabular}

${ }^{\mathrm{v}}$ Races are listed in order of prevalence.

${ }^{w}$ Virulence (vir.) gene first identified.

${ }^{x}$ Rps genes deployed in soybean cultivar(s).

${ }^{\mathrm{y}}$ at $=$ atypical isolates. Such isolates of races $1,4,15,25$, and 48 killed $>30 \%$ but $<70 \%$ of the seedlings of the differentials listed after the \pm sign in Table 2

$\mathrm{z} *$ Lines containing the Rps 4 and Rps5 genes were not included in the differential set prior to 1994. 
collected between 1979-80 and 1988-89 at the Station were typical or atypical race 1 , but race 15 was recorded for the first time in 1988-89 from soil isolations and a year later from infected seedlings of Davis (Table 3). Between 1989-90 and 1995-96, 218 isolates were collected and classified, 110 of which were obtained from the bulk planting of Ruse in 1993-94 and 66 from a bulk planting of Ross in 1995-96 (Table 5). The remainder were isolated from advanced breeding lines. Isolates of typical and atypical race 15 were the most common isolates, and nine other races, 1 (typical and atypical), 48 (typical and atypical), 4 (typical and atypical), 2 (typical and atypical), 10, 50, 51, and 52, were found. Some isolates collected in 1992-93 and 1993-94 were virulent on genes Rps6 and Rps 7 and were designated race 13, but upon retesting in 1995-96, they were found to be also virulent on the Rps4 gene (race 50). Soybean genotypes with the resistance gene Rps 2 comprised most of the material grown at Hermitage Research Station, but others with the resistance genes Rps $1 \mathrm{c},-1 \mathrm{k}$, and -3a have also been grown. Only race 1 isolates were found in trial plots at Narrabri, inland northern New South Wales, while at Gatton, in the Moreton district of southern Isolates of race 15 and atypical race 15 were collected from a trial site in the Burdekin Irrigation Area in 1989-90, which was the first record of $P$. sojae from the tropics in Australia.

Trial sites: Central and southern New South Wales and northern Victoria. One hundred nineteen isolates of the 149 isolates from trial sites in this region (Table 3) were collected from the LIRAC trial site at Condobolin in the Upper Lachlan Valley, including 97 from bulk plantings of Ruse in 1993-94 and 1994-95. Four races, typical and atypical race 4 , (which together comprised $94 \%$ of the isolates), typical and atypical race 25 , race 47 , and race 49 , were identified from the LIRAC site. The race Queensland, a race 2 isolate was identified.

25 isolates were from Banjalong, as reported above, the one isolate of race 41 was from an unidentified breeding line in 1993-94, and the race 49 isolate was from the bulk planting of cv. Ruse in 1994-95. Breeding lines and cultivars with the $R p s 1 \mathrm{k}$ gene have comprised the majority of genotypes grown at the LIRAC site since the mid-1980s (T. Bernardi, personal communication). At a trial site in the Murrumbidgee Valley (Colleambally Irrigation Area) and one of the sites in the Murray Valley (Finley), all isolates were typical or atypical race 4 , whereas at the Leeton/Yanco sites, five of the six isolates collected were race 4 and the other was race 1 .

\section{DISCUSSION}

Fourteen races of $P$. sojae have been identified in Australia since the pathogen was first discovered in 1979. Different and more complex races were found at trial sites compared to commercial soybean crops. Changes in the race structure of $P$. sojae in Australia, and differences in the racial composition between commercial crops and field sites, can be directly related to the exposure of pathogen populations to specific Rps genes. Race 1 was the dominant race both in Queensland and New South Wales up until 1989 (10; present study), during which time none of the affected commercial cultivars possessed any Rps genes. In 1989, race 4 was found on Ridley and Lachlan, which had been released in central and southern New South Wales in 1982-83 and 1987-88, respectively, and later on other commercial cultivars in the two areas (22; present study). Both cultivars were susceptible to race 4 and immune to races 1 and 15 based on hypocotyl inoculation (22), and it is highly likely that both possess the Rpsla gene, because one of their parents, Calland, possesses the Rpsla gene (39). Race 25 has been found at three sites in the Lachlan Valley of southern New South Wales on a new cultivar, Banjalong, believed to pos-

Table 5. Numbers of isolates of Phytophthora sojae races collected from the cultivar Ruse in 199394 and the cultivar Ross in 1995-96 at Hermitage Research Station, Queensland

\begin{tabular}{llcc}
\hline Race & Virulence genes & $\mathbf{1 9 9 3 - 9 4}$ & $\mathbf{1 9 9 5 - 9 6}$ \\
\hline 1 & 7 & 16 & 12 \\
$1 \mathrm{at}^{\mathrm{y}}$ & $7 \pm 1 \mathrm{~b}, 1 \mathrm{c}, 5,6$ & 7 & 12 \\
2 & $1 \mathrm{~b}, 7$ & 1 & 1 \\
$2 \mathrm{at}$ & $1 \mathrm{~b}, 7 \pm 1 \mathrm{c}, 5,6$ & $\ldots$ & 1 \\
4 & $1 \mathrm{a}, 1 \mathrm{c}, 7$ & 4 & 1 \\
10 & $1 \mathrm{~b}, 3 \mathrm{a}, 5,7$ & 1 & $\ldots$ \\
15 & $3 \mathrm{a}, 5,7$ & 56 & 25 \\
$15 \mathrm{at}$ & $3 \mathrm{a}, 5,7 \pm 1 \mathrm{a}, 1 \mathrm{~b}, 6$ & 6 & 5 \\
48 & 5,7 & 12 & $\ldots$ \\
$48 \mathrm{at}$ & $5,7 \pm 1 \mathrm{~b}, 1 \mathrm{c}, 6$ & $\ldots$ & 6 \\
50 & $4,6,7$ & $7 \mathrm{z}$ & 1 \\
51 & $1 \mathrm{c}, 5,6,7$ & $\ldots$ & 1 \\
52 & $3 \mathrm{~b}, 5,7$ & $\ldots$ & 1 \\
\hline
\end{tabular}

${ }^{y}$ at $=$ atypical isolates. Such isolates of races $1,2,15$, and 48 killed $>30 \%$ but $<70 \%$ of the seedlings of the differentials listed after the \pm sign.

${ }^{\mathrm{z}}$ Isolates were virulent on the Rps6 and Rps7 genes and were designated as race 13. Subsequent retesting in 1995-96 revealed that they were also virulent on the Rps 4 gene. sess the Rps $1 \mathrm{k}$ gene. The appearance of race 25 at one of the sites was unexpected because no soybeans had been grown there for the previous 7 years.

Until 1985, none of the commercial cultivars in Queensland, apart from Davis (which carries Rps2), had any genes for resistance. With the widespread adoption of Davis and other cultivars with a Davis background, such as Manark and Centaur in southern Queensland, the incidence and severity of Phytophthora root rot in this region declined dramatically. From 1989 onward, the proportion of race 15 isolates compared with race 1 isolates in southern Queensland increased significantly, and all the isolates of this race were recorded on cultivars with a Davis background. Root inoculation experiments showed that although Davis, Manark, and Centaur had high levels of field resistance to race 1 , they were susceptible to race 15 (21). The almost exclusive use of Davis-derived genotypes in the mid and late 1980s appears to have exerted considerable selection pressure on the pathogen population, resulting in an increase in the proportion of race 15 isolates.

The pathogenic populations at the two major trial sites (Hermitage Research Station, Warwick, and LIRAC, Condobolin) were much more diverse and complex than those in commercial crops. The composition of the $P$. sojae populations at the trial sites are influenced by a number of interacting factors: first, the diversity of $R p s$ genes planted in disease nurseries, second, the relative proportions of the different $R p s$ genes planted, and third, the more intensive sampling. There is a more complex racial structure at Hermitage Research Station, where more Rps genes have been tested, than at LIRAC, where only one or two Rps genes have been tested over the past 6 years. The relative proportions of Rps genes also has an influence. Until 1989 , all isolates collected from the nurseries at Hermitage Research Station were race 1 or atypical race 1 , but since then race 15 has been the dominant race in the populations. Breeding lines containing the Rps 2 gene have comprised a large proportion of the material grown on these sites since the early 1980s, and the dominance of this race at Hermitage Research Station can be correlated with prolonged exposure to this gene. Intensive sampling at Hermitage Research Station has resulted in races that comprise only a very small part of the population being identified, and these races may never have been found otherwise. In the United States, Schmitthenner et. al. (25) reported that many new undescribed races were isolated at low frequencies using nonselective baits, and they concluded that $P$. sojae exists in the soil in a wide variety of virulence phenotypes.

Population genetic research using DNA markers such as RFLPs has demonstrated low levels of genotypic diversity among 
Australian isolates of $P$. sojae $(7,38)$. Among a population of 84 isolates including five different races $(1,4,13,15$, and $\mathrm{X}$ [now designated 46]), more than $95 \%$ belonged to the same RFLP genotype (7). Additional races tested since then contained this same allelic background, suggesting mutation and rare outcrossing among different races as the two vehicles responsible for the occurrence of new races. Isolates collected in the late 1970s and early 1980s were genetically identical to those collected in subsequent years. In contrast, isolates from the United States were much more diverse $(6,9)$.

It has been recognized for some time that single allelic resistance, conditioning a hypersensitive response in the host plant, does not offer long-term protection against $P$. sojae, and cultivars with such resistance are confined to well-drained soils where the potential damage from the pathogen is minimal (23). The appearance and subsequent domination of race 4 in central and southern New South Wales after the widespread deployment of the Rps1a gene provides an example of the short life of cultivars with single-gene resistance. The use of cultivars with partial resistance, also referred to as field resistance (21), tolerance (34), rate-reducing resistance $(30,32)$, and root resistance $(27,28)$ has been advocated by many authors. Rps 2 is the only resistance gene that has been identified as conferring this type of resistance (13), but some workers have suggested that other as yet unidentified genes may also be responsible (27). Partial resistance was thought to be race nonspecific and would not favor the buildup of one race over another $(24,30)$, but Thomison et. al. $(27,28)$ demonstrated that the "tolerant" cultivars York and Ware, Celeste, and Ripley were resistant to race 1 and susceptible to race 10 . The first two cultivars were derived from CNS, which carries the Rps 2 gene (11). In a similar study, Ryley and Obst (21) showed that Davis, Manark, and Centaur were resistant to race 1 and susceptible to races 4 and 15 . The increase of race 15 in southern Queensland can be directly correlated with the dominance of Davis and Davis-derived lines carrying the Rps2 gene, and it is evident that the use of some forms of partial resistance results in changes in pathogenic populations of $P$. sojae in a similar fashion to resistance that confers a hypersensitive response.

Pyramiding resistance genes offers one method of reducing the risk of new virulent races appearing (25). Cultivars such as Keller, Miami (both with Rps1c and Rps3), and Winchester (Rps $1 \mathrm{~b}$ and $R p s 3$ ) have been grown extensively in the southern United States $(15,25)$, and others with combinations of three genes have been developed. The long-term effectiveness of pyramiding must be assessed because races with virulence to cultivars with two Rps genes have been reported by Schmitthen- ner (23), Tooley et. al. (31), and Walker (33). However, the cultivar Warrigal, developed by the Queensland Department of Primary Industries soybean breeding program, is believed to contain the genes Rps $1 \mathrm{c}$ and Rps2, and since its release in 1992, there have been no reports of its resistance being overcome. A number of possible combinations of resistance genes are still available to soybean breeders in Australia. Of the known Rps genes, only Rps $1 \mathrm{~d}$ and Rps $3 \mathrm{c}$, when used singly, will provide protection against all races of $P$. sojae found in Australia. However, only races $1,4,15,25,46$, and 53 (covering Rps 1a, -1b, -1c, -1k, -3a, -5, and -7) have been found in commercial situations, and of these, only races 1 and 15 (Rps3a, -5, and -7) have been found in Queensland. There is still considerable scope for pyramiding resistance genes that have not previously been exposed and deploying them in different soybean growing areas in Australia; in Queensland, various combinations of the genes Rps $1 \mathrm{~d},-1 \mathrm{k},-3 \mathrm{~b},-3 \mathrm{c},-4$, and -6 would prove effective, while in southern Australia the effective genes would include Rps 1d, -3b, -3c, -4, and -6. The use of genotypes with the Rps 2 gene and other forms of partial resistance should not be ignored, because although this gene can be defeated by some races, losses in field situations have not been severe. Recent research by Whisson et. al. $(36,37)$ has demonstrated absolute cosegregation between the avirulence (Avr) genes, Avrlb and $A v r 1 \mathrm{k}$, and $A v r 4$ and Avr6. If these gene combinations are used, it may be possible that one mutation in the pathogenic population could result in the defeat of both genes at the same time. On the other hand, it is highly unlikely that low levels of outcrossing between races with virulence on $R p s 4$ or Rps 6 will give rise to progeny that can overcome both Rps genes. More research on the clustering of pathogenic avirulence genes and the frequency of outcrossing among existing races is needed to determine optimum resistance gene combinations. The identification of pyramided genes in a soybean breeding line poses a problem when isolates with the necessary virulence patterns are unavailable. DNA marker-assisted breeding and the use of overseas races and progeny from crosses between different races for inoculations under quarantine conditions offer a solution to this problem (4).

In July 1975, a uniform set of seven soybean differentials was adopted by soybean workers to differentiate between races of $P$. sojae (14). The genes each differential contained were characterized later. This differential set, with occasional substitutions, was used to identify the first 24 races, but Williams 82, containing the $R p s 1 \mathrm{k}$ gene, was used by Layton et. al. (15) to characterize race 25. More recently, Harosoy and Williams isolines containing singly all known resistance genes have been developed by R. I. Buzzell and R. L. Bernard. Despite the use of genetically characterized differentials, there are examples of different virulence patterns for a number of races. According to Buzzell and Anderson (4), race 7 is virulent on Rps1a, $3 \mathrm{a},-3 \mathrm{c},-4,-5,-6$, and -7 , while Förster et. al. (9) listed it as virulent on Rps1c in addition to those above. Races 8 and 9 were reported by Buzzell and Anderson (4) to be virulent on Rps1a, -1d, -3c, -4, -6, and -7, and Rps 1a, -3c, -4, -6, and -7 , respectively; and Förster et. al. (9) considered that both races were also virulent on Rps5. Race 16 has been described as having three virulence patterns, Rps $1 \mathrm{~b},-1 \mathrm{c},-1 \mathrm{k}$, and -3 by Buzzell and Anderson (4); Rps1b, -1c, -1k, $-3 a$, and $-3 b$ by Förster et. al. (9), and $R p s 1 \mathrm{~b},-1 \mathrm{c},-1 \mathrm{k}$, and -5 by Ward (35).

The differences in virulence patterns may be due to the use of different differential sets, mislabeling of cultures, contamination, changes of virulence in culture, and differences in inoculation techniques and incubation conditions adopted by various workers. Considerable effort has been made in recent years in developing isolines containing different Rps genes, and it is now time for the development and adoption of standard techniques for classifying isolates of $P$. sojae. In addition, a reference collection of type isolates of each race, with an easily accessible database, must be established, and the isolates must be stored by a method (such as liquid nitrogen) that minimizes the possibility of changes in virulence over time. As isolates with previously undescribed virulence patterns are discovered, they can be added to the collection and assigned a race number or other form of identification.

\section{ACKNOWLEDGMENTS}

We thank I. Rose and J. Andrews for reviewing the manuscript, W. Martin, H. Mosetter, and S. Thompson for technical support, and R. I. Buzzell and R. L. Bernard for seed of the differential sets. Financial support was provided by the Grains Research and Development Corporation (Australia) and the Cooperative Research Centre for Tropical Plant Pathology, University of Queensland.

\section{LITERATURE CITED}

1. Abney, T. S., Melgar, J. C., Richards, T. L., Scott, D. H., Grogan, J., and Young, J. 1997. New races of Phytophthora sojae with Rps1-d virulence. Plant Dis. 81:653-655.

2. Anderson, T. R., and Buzzell, R. I. 1992 Diversity and frequency of races of Phy tophthora megasperma f. sp. glycinea in soybean fields in Essex County, Ontario, 19801989. Plant Dis. 76:587-589.

3. Anderson, T. R., and Buzzell, R. I. 1992. Inheritance and linkage of the Rps 7 gene for resistance to Phytophthora rot of soybean. Plant Dis. 76:958-959.

4. Buzzell, R. I., and Anderson, T. R. 1992. Inheritance and race reaction of a new soybean Rps1 allele. Plant Dis. 76:600-601.

5. Dhingra, O. D., and Sinclair, J. B. 1985. Basic Plant Pathology Methods. CRC Press, Boca Raton, FL.

6. Diers, B. W., Mansur, L., Imsande, J., and Shoemaker, R. C. 1992. Mapping Phy- 
tophthora resistance loci in soybean with restriction fragment length polymorphism markers. Crop Sci. 32:377-383.

7. Drenth, A., Whisson, S. C., Maclean, D. J., Irwin, J. A. G., Obst, N. R., and Ryley, M. J. 1996. The evolution of races of Phytophthora sojae in Australia. Phytopathology 86:163169.

8. Eckert, J. W., and Tsao, P. H. 1962. A selective antibiotic medium for isolation of Phytophthora and Pythium from roots. Phytopathology 52:771-772.

9. Förster, H., Tyler, B. M., and Coffey, M. D. 1994. Phytophthora sojae races have arisen by clonal evolution and by rare outcrosses. Mol. Plant-Microbe Interact. 7:780-791.

10. Heritage, A. D., Castles, C. J., and Pierpoint, J. A. 1993. Surveys of Phytophthora root and stem rot in early maturing soybean crops in southern temperate regions of Australia from 1985 to 1988. Australas. Plant Pathol. 22:131135.

11. Hymowitz, T., Newell, C. A., and Carmer, S. G. 1977. Pedigrees of Soybean Cultivars Released in the United States and Canada. INTSOY Ser. 13. University of Illinois, Urbana

12. Irwin, J. A. G., and Langdon, P. W. 1982. A laboratory procedure for determining relative levels of field resistance to Phytophthora megasperma f. sp. glycinea. Aust. J. Agric. Res. 33:33-39.

13. Kilen, T. C., Hartwig, E. E., and Keeling, B. L. 1974. Inheritance of a second major gene for resistance to Phytophthora rot in soybeans. Crop Sci. 14:260-262.

14. Laviolette, F. A., and Athow, K. L. 1981. Physiologic races of Phytophthora megasperma f. sp. glycinea in Indiana, 1973-1979. Plant Dis. 65:884-885

15. Layton, A. C., Athow, K. L., and Laviolette, F. A. 1986. New physiologic race of Phytophthora megasperma f. sp. glycinea. Plant Dis. 70:500-501.

16. Pegg, K. G., Kochman, J. K., and Vock, N. T. 1980. Root and stem rot of soybean caused by Phytophthora megasperma var. sojae. Australas. Plant Pathol. 9:15.

17. Rennie, B. D., Buzzell, R. I., Anderson, T. R., and Beversdorf, W. D. 1992. Evaluation of four Japanese soybean cultivars for Rps alleles conferring resistance to Phytophthora megasperma f. sp. glycinea. Can. J. Plant Sci. 72:217-220.

18. Rose, J. L., Irwin, J. A. G., Ryley, M. J., Langdon, P. W., and Jenner, L. B. 1982. Reaction of soybean cultivars to races of Phytophthora megasperma f. sp. glycinea present in Queensland. Aust. J. Agric. Res. 33:763771.

19. Rose, J. L., and Mungomery, V. E. 1985. The contribution of science to Australian tropical agriculture. 7. Oilseeds and fibre crops. J. Aust. Inst. Agric. Sci. 51:64-73.

20. Ryley, M. J., Mosetter, H. F., and Rose, J. L. 1989. Yield losses of soybeans due to Phytophthora megasperma f. sp. glycinea. Aust. J. Agric. Res. 40:1161-1169.

21. Ryley, M. J., and Obst, N. R. 1992. Racespecific resistance in soybean cv. Davis to Phytophthora megasperma f. sp. glycinea. Plant Dis. 76:665-668.

22. Ryley, M. J., Obst, N. R., and Stovold, G. E. 1991. A new race of Phytophthora megasperma f. sp. glycinea on soybean in Australia. Australas. Plant Pathol. 20:97-102.

23. Schmitthenner, A. F. 1985. Problems and progress in control of Phytophthora root rot of soybean. Plant Dis. 69:362-368.

24. Schmitthenner, A. F. 1988. Phytophthora rot of soybean. Pages 71-80 in: Soybean Diseases of the North Central Region. T. D. Wylie and D. H. Scott, eds. American Phytopathological Society, St. Paul, MN.

25. Schmitthenner, A. F., Hobe, M., and Bhat, R. G. 1994. Phytophthora sojae races in Ohio over a 10-year interval. Plant Dis. 78:269276.

26. Suhovecky, A. J., and Schmitthenner, A. F. 1955. Soybeans affected by early root rot. Ohio Farm Home Res. 40:85-86.

27. Thomison, P. R., Thomas, C. A., and Kenworthy, W. J. 1991. Tolerant and root resistant soybean cultivars: Reactions to Phytophthora rot in inoculum-layer tests. Crop Sci. 31:7375 .

28. Thomison, P. R., Thomas, C. A., Kenworthy, W. J., and McIntosh, M. S. 1988. Evidence of pathogen specificity in tolerance of soybean cultivars to Phytophthora rot. Crop Sci. 28:714-715.

29. Tooley, P. W., Bergstrom, G. C., and Wright, M. J. 1984. Widely virulent isolates of Phy- tophthora megasperma f. sp. glycinea causing root and stem rot in New York. Plant Dis. 68:726-727.

30. Tooley, P. W., and Grau, C. R. 1986. Microplot comparison of rate-reducing and rate specific resistance to Phytophthora megas perma f. sp. glycinea in soybean. Phytopathology 76:554-557.

31. Tooley, P. W., Grau, C. R., and Stough, M. C. 1982. Races of Phytophthora megasperma $\mathrm{f}$ sp. glycinea in Wisconsin. Plant Dis. 66:472 475.

32. Wagner, R. E., Carmer, S. G., and Wilkinson, H. T. 1993. Evaluation and modeling of ratereducing resistance of soybean seedlings to Phytophthora sojae. Phytopathology 83:187192.

33. Walker, A. K. 1985. Breeding for the management of soybean root and stem diseases. Pages 418-426 in: Proc. World Soybean Res. Conf. III. Westview Press, Boulder, CO.

34. Walker, A. K., and Schmitthenner, A. F. 1984 Comparison of field and green house evaluations for tolerance to Phytophthora rot in soybean. Crop Sci. 24:487-489.

35. Ward, E. W. B. 1983. Effects of mixed or consecutive inoculations on the interaction of soybeans with races of Phytophthora mega sperma f. sp. glycinea. Physiol. Plant Pathol. 23:281-296.

36. Whisson, S. C., Drenth, A., Maclean, D. J and Irwin, J. A. G. 1994. Evidence for outcrossing in Phytophthora sojae and linkage of a DNA marker to two avirulence genes. Curr. Genet. 27:77-82

37. Whisson, S. C., Drenth, A., Maclean, D. J., and Irwin, J. A. G. 1995. Phytophthora sojae avirulence genes, RAPD, and RFLP markers used to construct a detailed genetic linkage map. Mol. Plant-Microbe Interact. 8:988-995

38. Whisson, S. C., Maclean, D. J., Manners, J. M., and Irwin, J. A. G. 1992. Genetic relationships among Australian and North American isolates of Phytophthora megasperma f. sp. glycinea assessed by multicopy DNA probes. Phytopathology 82:863-868.

39. Wilcox, J. R. 1976. Breeding for root resistance. Pages 485-490 in: World Soybean Research. L. D. Hill, ed. Interstate Printers and Publishers, Danville, IL. 